\title{
Massachusetts Health Reform: A Social Compact and a Bold Experiment
}

\author{
Christie L. Hager*
}

I. INTRODUCTION

A sweeping health care reform law, enacted in Massachusetts in April 2006, during the 2005-2006 session of the Massachusetts General Court, has become the catalyst for renewed discussion and action among states seeking to address the growing problem of the medically uninsured. Expanding access to health coverage for the uninsured represents one of the greatest challenges to states, particularly at a time when the federal government is enacting significant reductions in the Medicaid program, long an essential component of states' safety net for their uninsured. As the list of possible state legislative solutions grows to include Medicaid expansion, public-private partnerships, private insurance market reforms, public insurance subsidies, employer contributions, and individual mandates, the Massachusetts legislature approved a package that boldly combined all of the above.

"An Act Providing Access to Affordable, Quality, Accountable Health Care,"1 or "Chapter 58," represents a comprehensive legislative package that was developed over a period of fifteen months and whose full implementation will span more than three years. In a single legislative package of 147 sections, Chapter 58 of the Massachusetts Acts of 2006 amends twenty-two sections of the Massachusetts General Laws, and either affects or creates approximately twenty-two state entities. At its full implementation, it is projected to result in insurance coverage for nearly all of the Commonwealth's 372,000 uninsured residents. ${ }^{2}$ With a three-year timeline for full implementation, its many

\footnotetext{
- Chief Health Counsel to the Massachusetts Speaker of the House of Representatives, Salvatore F. DiMasi.

1. An Act Providing Access to Affordable, Quality, Accountable Health Care, ch. 58, 2006 Mass. Acts (forthcoming), available at http://www.mass.gov/legis/laws/seslaw06/s1060058.htm [hereinafter An Act Providing Access to Health Care].

2. Jeffrey Krasner, Senator Says Health Plan Rates Too High: Low-Income Residents Could Be Priced Out By Proposal, He Warns, Boston Globe, Aug. 31, 2006, at E1 (stating that Massachusetts estimates its insured at 372,000 ).
} 
moving parts are delicately balanced and dependent upon the progress of the rest.

Chapter 58 consists of a combination of a new public insurance subsidy program for income-eligible individuals administered by a new, quasi-public health insurance "connector;" reforms and innovations in the private insurance market, including the creation of new, affordable products; expansions and restoration of Medicaid benefits; increases in reimbursements for Medicaid providers, which become contingent on compliance with new pay for performance measures; new efforts to address health care cost containment and quality improvement and to reduce racial and ethnic health disparities; a redirection of existing Uncompensated Care Pool expenditures to fund insurance for the currently uninsured; new requirements for employers to contribute to the health care costs of their workers; and a first in the nation requirement for all individuals age eighteen and older to purchase health insurance if it is affordable to them.

Given the vast scope of its provisions, it is not surprising that Chapter 58 is replete with opportunity for analysis of new and recurring legal issues in moving toward the goal of universal health insurance on the state level and the reaffirmation of health insurance as a social good. The complexity of its statutory and regulatory construction and the politics of the jurisdiction in which it was developed combine to present Chapter 58 as an interesting example of state health policymaking.

\section{A SOCIAL COMPACT FOR SHARED RESPONSIBILITY}

The Massachusetts Constitution, the oldest in the nation (and therefore in the world), describes a "voluntary association of individuals ... all [of which] shall be governed by certain laws for the common good." 3 In language adopted in 1780 from the Mayflower Compact, it describes a social compact for a Commonwealth, ${ }^{4}$ and served as the inspiration for the primary principle on which Chapter 58 is based-shared responsibility. For the first time, individuals would be required to purchase health insurance if affordable to them, the government would help them to afford it by investing hundreds of millions of dollars in subsidies for the purchase of health insurance, and employers would for the first time be asked to contribute to the health of their own workers.

3. MASS. CONST. pmbl.

4. Id. 


\section{A. Background and Context}

The context in which Chapter 58 was developed is important to consider, as the policy and political circumstances shaped what was ultimately the consensus solution to address the problem of uninsurance in Massachusetts. There are many significant features and characteristics of Massachusetts that distinguish it from other jurisdictions in ways that present unique opportunities and challenges alike.

As the beginning of 2005 approached, the Massachusetts General Court was preparing to begin meeting in its 2005-2006 biennial session, and the Romney Administration was negotiating a renewal of the Commonwealth's Medicaid Section 1115 waiver, under which it had been operating the MassHealth program, including the State Children's Health Insurance Program, with the federal Centers for Medicare and Medicaid Services. The federal government was clear in its directive that renewal of the waiver for another three-year period would be largely dependent upon the satisfactory shift of funds currently spent through the state's Uncompensated Care Pool in the form of payments to hospitals that serve the uninsured to funds to support the purchase of health insurance products for uninsured individuals. Approval of certain provisions of the renewal of the Medicaid waiver was the most basic "must do list" for the Legislature because it would preserve approximately $\$ 385$ million in federal funds over the term of the new waiver.

There are several features that distinguish Massachusetts in ways that bear on the successful passage of Chapter 58, from both a policy and political standpoint. An Uncompensated Care Pool was created in 1985 to provide support for uninsured and underinsured residents of the Commonwealth. This safety net, created as a financing mechanism for hospital and community health center care provided to uninsured individuals, has been funded in previous years by a combination of public sector contributions in the form of intergovernmental transfers from federal funds and state appropriations, along with private sector contributions in the form of assessments from insurers and hospitals. In 2006 , charges to the Uncompensated Care Pool exceeded $\$ 1$ billion for services provided to over 400,000 individuals, $80 \%$ of whom were below $200 \%$ of the Federal Poverty Level (FPL) $(\$ 19,500) .^{s}$

5. Massachusetts Division of Health Care Finance \& Policy, Uncompensated Care POOL QUARTERLY REPORT, FY06 Q3 3 -4 (2006), available at http://www.mass.gov/Eeohhs2/docs/ dhcfp/p/ucp/pfy06_q3.pdf. 
Massachusetts has also experienced a higher than average rate of Employer Sponsored Insurance (ESI) as compared with other states. Based on a robust biennial survey of Massachusetts employers conducted by the state Division of Health Care Finance and Policy (another advantage for Massachusetts health policymaking), over $97 \%$ of employers with more than fifty workers offered insurance to their workers in 2005 , as did $70 \%$ of employers overall. ${ }^{6}$ Indeed, those employers who did contribute to the health insurance of their workers were subsidizing free care provided to uninsured workers through insurance surcharges paid to the Uncompensated Care Pool. This lack of equity and a solid foundation of voluntary ESI made it probable that employers would participate in a system where all employers would be required to share the financial responsibility of their workers' health.

An historically low rate of uninsurance was due in large part to the success of the one million-plus-member MassHealth program, including aggressive outreach and enrollment and a generous schedule of eligibility and optional state services. ${ }^{7}$ The successful MassHealth program and high rate of ESI contributed largely to the historically low rate of uninsured. Although the number was creeping upwards as 2005 approached, $7.4 \%$ of the state's 6.2 million population was uninsured according to the state survey conducted in 2004 (compared to the U.S. rate of $15.7 \%$ ). The same survey revealed interesting demographics of the uninsured-most were employed, $43 \%$ were between the ages of 19 34 , and a growing number were adults in their 50 's. ${ }^{8}$

Consumer-oriented insurance regulation by the state Division of Insurance had established a base upon which innovative reforms could be built to enhance affordability and access for the uninsured, as well as existing non and small-group purchasers of health insurance. The Massachusetts private insurance market already included guaranteed issue and modified community rating, with no medical underwriting and a history of insurance regulators disapproving products with high deductibles and slim benefits. It is also worth noting that of the top five

6. Massachusetts Division of Health Care Finance \& Policy, Massachusetts EMPLOYER HEALTH INSURANCE SURVEY, (2005), available at http://www.mass.gov/Eeohhs2/docs/ dhcfp/r/survey/emp_hsi_results_yr.pdf.

7. For a comprehensive history of, and policy analysis materials related to, the Massachusetts Medicaid program, including MassHealth, see the Massachusetts Medicaid Policy Institute, http:// www.massmedicaid.org (last visited May 20, 2007).

8. Massachusetts Division of Health Care Finance \& Policy, Health Insurance Status OF MASSACHUSETTS RESIDENTS 3-19 (4th ed. 2004), available at hitt://www. statecoverage.net/statereports/ma5l.pdf. 
health insurers, in terms of enrollment, in the Commonwealth, four of them are Massachusetts-based, non-profit companies.

Legislative work in Massachusetts was informed by analysis commissioned by the Blue Cross Blue Shield of Massachusetts Foundation and published in 2004 and 2005 by the Urban Institute. ${ }^{9}$ This objective policy analysis was a key catalyst to progress by the legislature and provided recent, sound analysis of various policy options tailored to the picture of the uninsured in the Commonwealth.

Finally, the political landscape in Massachusetts is marked with active and powerful stakeholder coalitions, notably organized in collaboration by consumer, provider, and business organizations. In particular, the campaign for expanding access during the development of Chapter 58 saw unprecedented involvement of the faith community, which continues as a powerful and numerous constituency of healthrelated issues.

\section{B. Legislative Context}

The window of opportunity for legislative action was opened by a convergence of factors, including the need for preservation of federal Medicaid funds. It was pushed open even wider by the alignment of the respective political wills of Governor Mitt Romney, Speaker Salvatore F. DiMasi, and Senate President Robert Travaglini. All three leaders identified health access expansion as a priority even before the start of 2005. The context provided by certain matters before the General Court drove the momentum of the health access agenda.

Massachusetts is one of the twenty-four states that have an initiative petition process for placing matters on the ballot in statewide elections. ${ }^{10}$ The General Court considered placing two initiative petitions on the November 2006 ballot. One was an initiative petition for a constitutional amendment, which would require the legislature to enact laws ensuring that no Massachusetts resident lacks health insurance coverage. The

9. See generally, Linda J. BlumberG, ET AL. BuIlding THE RoAdmap to Coverage: Policy ChoICES AND THE COST AND COVERAGE IMPlications (2005); Alison COOK, HEALTH INSURANCE COVERAGE AND THE UNINSURED IN MASSACHUSETTS (2005); JOHN HOLAHAN, ET AL., CARING FOR THE UNINSURED IN MASSACHUSETTS: WHAT DOES IT COST, WHO PAYS AND WHAT WOUld FUll COVERAGE AdD to MEDICAL SPENDING? (2004); JOHN HOLAHAN, ET AL., ROADMAP TO COVERAGE: SYNTHESIS OF FINDINGS (2005). ALAN WEIL, YOU CAN GET THERE From HERE: IMPLEMENTING THE ROADMAP TO COVERAGE (2005). These reports are available online at http:// www.roadmaptocoverage.org/pubs/main.html.

10. National Conference of State Legislatures, http://www.nesl.org/programs/legismgt/elect/ initiat.htm (last visited Apr. 30, 2007). 
other initiative petition, filed by the ACT! Coalition, a group organized by the statewide health consumer organization Health Care For All, ${ }^{11}$ was for a law including significant Medicaid expansion, a payroll tax on employers (referred to as an "employer health access assessment"), and a fifty-cent increase in the state cigarette excise tax.

Many legislators responded by cosponsoring bills to address the same issue of the uninsured. As a result, several major legislative vehicles emerged for consideration during the 2005-2006 Session of the General Court.

One bill, filed with joint House and Senate sponsorship, largely mirrored the provisions of the initiative petition filed by the ACT! Coalition included, inter alia, expansion of Medicaid eligibility for those up to $200 \%$ of FPL, sliding scale subsidies for people between 200 $400 \%$ of FPL, and a 50 -cent cigarette state excise tax increase. ${ }^{12}$

A bill sponsored by the President of the Senate, Robert Travaglini, purported to cover half of the Commonwealth's uninsured over a period of two years, with minimal Medicaid expansion and a so-called "Free Rider" provision-requiring employers to reimburse the state for certain services provided to uninsured workers and their dependents. ${ }^{13}$

Governor Romney filed three separate bills. One would create a Health Insurance Exchange to facilitate the purchase of private health insurance products by individuals and employees of small businesses. ${ }^{14}$ This bill would also require employers to offer payroll deductions to

11. Member organizations include: American Cancer Society, American Heart/American Stroke Association, Artists Foundation, Inc., Boston Center for Independent Living, Boston Medical Center, Boston Public Health Commission, Cambridge Health Alliance, Children's Hospital Boston, Children's Health Access Coalition, Coalition for Social Justice, Families USA, Greater Boston Interfaith Organization, Health Care For All, Health Law Advocates, Home Care Alliance of Massachusetts, Massachusetts Academy of Family Physicians, Massachusetts Building Trades Council, Massachusetts Business Leaders for Quality, Affordable Health Care, Massachusetts Chapter of the American Academy of Pediatrics, Massachusetts College of Emergency Physicians, Massachusetts Communities Action Network, Massachusetts Community Health Worker Network, Massachusetts Council of Community Hospitals, MIRA Coalition, Massachusetts Health Council, Massachusetts Hospital Association, Massachusetts Law Reform Institute, Massachusetts League of Community Health Centers, Massachusetts Medical Society, Massachusetts NOW, Massachusetts Public Health Association, Mental Health and Substance Abuse Corporations of Massachusetts, Neighbor to Neighbor, Partners HealthCare, Public Policy Institute, SEIU Local 615, 1199 SEIU, Tobacco Free Mass, UMass Memorial Health Care, and Western Mass Health Access Coalition. More information can be found at www.hcfama.org/act.

12. HB 2777, 184th Gen. Ct., Reg. Sess. (Mass. 2005); S.B. 738, 184th Gen. Ct., Reg. Sess. (Mass. 2005).

13. See SB 2042, 184th Gen. Ct., Reg. Sess. (Mass. 2005) (discussing lowering the number of uninsureds).

14. H.B. 2924, 184th Gen. Ct., Reg. Sess. (Mass. 2005). 
their workers to apply toward their health insurance premiums. ${ }^{15}$ The other two bills would, among other provisions, create a Safety Net Care program, provide premium assistance for residents below $300 \%$ of FPL, and require all residents to obtair. health insurance or otherwise be liable for the costs of health care services provided to them. ${ }^{16}$

All but one of the filed bills ${ }^{17}$ were referred to and heard by the Joint Committee on Health Care Financing. This new committee, created at the start of the 2005-2006 session, held jurisdiction over matters related to the state's Medicaid program and health care finance. The remaining bill, creating the Health Insurance Exchange, was referred to the Joint Committee on Financial Services, another newly formed committee which combined the jurisdictions of the former Joint Committees on Insurance and Banks \& Banking. By September of 2006, all of the matters had been heard by the committees, and the Joint Committee on Health Care Financing began work on a redrafted bill that would incorporate elements of all of the bills before it.

The period during which the committee redrafted and recrafted the reform proposals before it was marked by intense lobbying by a broad array of stakeholders and interest groups. The range of provisions contained in all of the bills assured that every major perspective would seek to stake their respective grounds. The members of the ACT! Coalition remained active in advocating aggressive expansions in Medicaid and mandated contributions by employers in the form of a payroll assessment. Hospitals and community health centers came to and stayed at the table with hopes of fair reimbursement rates for care provided to Medicaid patients and of protection against uncompensated care costs. Business leaders, both small and large, urged lawmakers to relieve the burden on employers of increasing health premium costs.

In October 2006, the report released by the Committee on Health Care Financing was a surprise to both the entrenched left and the wellestablished right. It included both an individual mandate and new forms of responsibility for employers to take for the health care costs of their workers, including, but not limited to, a 3-5\% assessment on payroll to pay for the health care costs of workers whose employers did not provide health insurance. When the House of Representatives voted with an overwhelmingly veto-proof margin to approve the Committee Report,

\footnotetext{
15. Id.

16. HB 2923, 184th Gen. Ct., Reg. Sess. (Mass. 2005); H.B. 4297, 184th Gen. Ct., Reg. Sess. (Mass. 2005).

17. HB 2924, 184th Gen. Ct., Reg. Sess. (Mass. 2005).
} 
the Senate immediately substituted the proposal that had been filed by Senate President Travaglini. ${ }^{18}$

\section{Conference Committee}

The Senate's nonconcurrence with the House necessitated the appointment of a conference committee, consisting of two members of the majority party and one of the minority party in each chamber. Reconciling the two bills, which shared the goal of reducing the number of uninsured but employed significantly different approaches to meet that goal, would prove to be a lengthy and politically challenging process. The conference committee met over a period of four months and struggled with numerous discrepancies between the two versions. Under significant pressure from consumer advocates and employer groups, Senate and House members committed to consensus on difficult issues, particularly the employer-related provisions and application and enforcement of the individual mandate.

The House and Senate approved the Conference Committee report by overwhelming, and again, veto-proof margins. ${ }^{19}$ One week later, Governor Romney approved the bill in part, vetoing a total of eight sections, including coverage for certain disabled and elderly immigrants, restoration of previously cut optional state services for adult Medicaid enrollees, consultation between the executive and legislative branches in future Medicaid waiver negotiations, and the employer Fair Share Contribution. ${ }^{20}$ Within three weeks, both chambers passed the legislation, over the objections of the Governor, as they did more than 300 other times during the 2005-2006 legislative session.

\section{CONTENT OF THE CONFERENCE COMMITTEe REPORT}

The following summary of legislative provisions reflects the content of the Conference Committee Report and any subsequent changes made by technical amendment to Chapter 58 .

18. See SB 2042, 184th Gen. Ct., Reg. Sess. (Mass. 2005) (enacting Chapter 58)

19. HB 4850, 184th Gen. Ct., Reg. Sess. (Mass. 2006).

20. HB 4857, 184th Gen. Ct., Reg. Sess. (Mass. 2006). Because the bill contained appropriations, the bill was subject to line-item veto by the governor. 


\section{A. Commonwealth Health Insurance Connector Authority}

As a legislative drafting matter, Chapter 58 was a constant exercise in balancing statutory direction with administrative flexibility. With so many of its provisions representing novel policy initiatives and de novo solutions, and with the reality that the first several months of implementation and key appointments would be overseen and made by the outgoing Romney Administration, careful attention was paid to the statutory framework so it would act as a living vehicle for long-term innovative policy implementation. Perhaps the most stark example of such a balance is the creation of the Commonwealth Health Insurance Connector (Connector). The Connector, a new, quasi-public authority, was charged with implementing major components of the access expansion provided in Chapter 58. It is governed by a ten-member board, with three appointees designated by the Governor, three by the Attorney General, and four by virtue of their positions in the Administration. ${ }^{21}$ The Connector is designed to operate as a centralized distribution channel for certain new private market products, as a facilitator for purchase of insurance on behalf of employer groups of up to fifty workers, and as the administrator for the new Commonwealth Care Health Insurance Program.

The Connector will offer individuals and employer groups with up to fifty workers access to Section 125 plans, which enjoy the pre-tax purchase of health insurance, and will assume the administrative burden for small business policies. Workers with multiple employers may combine employer contributions and some policies may be portable as workers move from job to job.

The Connector is also charged with facilitating the sale of new, affordable products to be developed by the state's health insurers for sale to individuals with incomes greater than $300 \%$ of FPL. After months of discussions with the state's major insurers, the legislature conservatively projected that products with comprehensive benefits and reasonable deductibles could be developed with a target monthly premium of $\$ 320$.

\section{B. Commonwealth Care Health Insurance Program}

The Commonwealth Care Health Insurance Program ${ }^{22}$ provides full subsidies to individuals up to $100 \%$ of FPL (income of up to $\$ 9,800$ per

21. An Act Providing Access to Health Care, supra note $1, \S 101(2)(\mathrm{b})$.

22. Id. $\S 45$. 
year), with comprehensive benefits including mental health, dental, and vision. For individuals up to $300 \%$ of FPL (income of up to $\$ 49,800$ per year for a family of three), sliding scale subsidies are provided, with no deductibles. An estimated 200,000 of the uninsured will be eligible for Commonwealth Care. This program is expected to be most instrumental in relieving the burden on the Uncompensated Care Pool and its successor, Health Safety Net Fund, as data show that $80 \%$ of current Pool users are at or below $200 \%$ of FPL.

The four Medicaid Managed Care Organizations in the state ${ }^{23}$ were granted exclusive market in Chapter 58, subject to meeting stated annual enrollment targets, to enroll members in the new Commonwealth Care Health Insurance Program until July 20, 2009. ${ }^{24}$

\section{Medicaid Expansion, Enrollment, and Restoration of Benefits ${ }^{25}$}

The renewal of the Medicaid Section 1115 waiver opened the opportunity to strengthen the MassHealth program not only by expanding eligibility for certain members, but also by restoring previously cut benefits and raising enrollment caps that had been affected by changes in the state fiscal year 2002 budget. Eligibility for the State Children's Health Insurance Program was extended to children in families with incomes at $300 \%$ of FPL, up from $200 \%$ of FPL. Benefits, including vision, chiropractic, and prosthetics, were restored for adults in the MassHealth program. Further, enrollment caps were lifted to eliminate waiting lists in the MassHealth Essential, CommonHealth, and Family Assistance programs for individuals who are long-term unemployed, disabled, HIV-positive, or otherwise qualified individuals. Eligibility for the Insurance Partnership Program, a subsidy program for employers and employees, was increased from $200 \%$ to $300 \%$ of FPL. To ensure that not only newly eligible but also currently eligible unenrolled residents are identified and enrolled in the program, nearly $\$ 3$ million dollars were appropriated for targeted outreach and enrollment efforts by community-based organizations statewide.

It is hoped that the Commonwealth's Medicaid providers will care for tens of thousands more Medicaid patients under Chapter 58. A significant investment in hospitals, community health centers, and

23. Namely, Boston Medical Center HealthNet Plan, Fallon Community Health Plan, Neighborhood Health Plan, and Network Health.

24. An Act Providing Access to Health Care, supra note $1, \S 123$.

25. See An Act Providing Access to Health Care, supra note 1, $\S 15,17,19,20,21,22,23,26$, 27,29 for a comprehensive explanation of Chapter 58's changes to Massachusetts Medicaid. 
physicians who care for Medicaid enrollees is made in the form of long overdue increases in reimbursement rates amounting to more than $\$ 500$ million dollars over the course of the first three years of implementation. ${ }^{26}$ Beginning in year two of implementation, increased payments to hospitals will be contingent on meeting new pay for performance goals, to be established by a new Health Care Quality and Cost Council. ${ }^{27}$

\section{CONTROVERsies AND FutURe PROJeCtions}

\section{A. Uncompensated Care Pool Reform}

While it is projected that demand on the current Pool will be reduced by the expanded options for coverage, including MassHealth and Commonwealth Care, it is understood that there will remain some ongoing need for a safety net for the remaining uninsured and underinsured residents. The Commonwealth will maintain its funding commitment to the Pool as it is discontinued and replaced by a new Health Safety Net Fund. ${ }^{28}$ The Health Safety Net Fund will also shift its payment methodology from charge-based to fee-based, thus equalizing the reimbursement to institutions based on procedure instead of charges submitted. $^{29}$

\section{B. Private Insurance Market Reforms and Innovations}

Several reforms and innovations in the private market were made more easily achievable by preexisting, favorable regulatory conditions. With guaranteed issue and modified community rating already in place, measures aimed at further expanding the insurance risk pool were instituted by Chapter 58 .

The non-group and small-group markets were set to merge in 2007, thus combining the overall sicker individuals in the non-group market with those in the small-group markets. ${ }^{30}$ A special commission was created to examine the impact of such a merger, taking into account all of

26. An Act Providing Access to Health Care, supra note $1, \S 30(60)$.

27. Id. $\S 3(16 \mathrm{~J}-\mathrm{L})$. See also infra Part IV.C. for discussion of the Health Care Quality and Cost Council.

28. Id. $\S 30(57)$.

29. See id. $\S 60(1)$ (stating fund will make payments using fee-for-service rates).

30. See $i d$. $\S 81(176 \mathrm{~J})$ (applying Chapter 58 to all health benefit plans). 
the relevant provisions elsewhere in Chapter $58 .^{31}$ The Commission found that current non-group rates are expected to be reduced by $15 \%$, while small-group rates may rise a mere $1-1.5 \%$.

To address the large and growing number of adults aged 19-26 who are uninsured at greater than $300 \%$ of FPL, new products for young adults will be developed, pursuant to Chapter 58 , with specially designed benefits, coverage, and monthly premiums of less than $\$ 200$. Limits on coverage will be permitted, but benefits must be comprehensive. ${ }^{32}$

An additional measure to increase insurance participation by young adults is the requirement that insurers extend coverage under family policies to dependents until age 25 , or two years beyond loss of dependent status, whichever occurs first. ${ }^{33}$

To enhance the ability of the state's insurance regulators to implement the new laws that apply to health insurers and insurance, Chapter 58 creates a new Health Care Access bureau within the Division of Insurance. ${ }^{34}$ It directs the agency's commissioner to staff the new bureau with several specialized positions. ${ }^{35}$

\section{Quality and Cost}

Stemming the rises in health care costs and health insurance premiums are gargantuan challenges in themselves. While Chapter 58 focuses on increasing access to care for the Commonwealth's uninsured, important provisions put the Commonwealth on the right track to raise the profile of both quality improvement and cost containment in the delivery of and payment for health services. A new Health Care Quality and Cost Council is created within the Executive Office of Health and Human Services. ${ }^{36}$ The Council is chaired by the Secretary of Health and Human Services and is governed by a board with broad representation of stakeholders and constitutional officers, including the State Auditor, Inspector General, and Attorney General. It has the authority to promulgate regulations to enforce new requirements related to quality improvement and cost containment and is required to conduct annual public hearings to assure public input. ${ }^{37}$

\footnotetext{
31. Id. $\S 114$.

32. Id. $\S 90(10)$.

33. Id. $\S 49(108)$.

34. Id. $\S 6(7 \mathrm{~A})$.

35. Id.

36. Id. $\S 3(16 \mathrm{~K})$.

37. Id. $\S 3(16 \mathrm{~L})$.
} 


\section{Public Health}

While preventive and wellness care is woven throughout the access provisions of the new law, public health and prevention is addressed directly through appropriations contained in Chapter 58. Approximately $\$ 15$ million dollars in appropriations is applied to various Department of Public Health programs, including, but not limited to, smoking cessation, prostate and breast cancer screening, and teen pregnancy prevention. ${ }^{38}$

\section{E. Racial and Ethnic Health Disparities}

Reducing and eliminating racial and ethnic health disparities is an explicit goal of Chapter $58 .^{39}$ Increased provider Medicaid reimbursement must consider cultural and linguistic barriers and the measurement of reductions in disparities. ${ }^{40}$ Providers will be required to collect and report data on disparities. And, a new Health Disparities Council will be appointed by July 2007 with broad representation to institutionalize efforts aimed at reducing disparities in the Commonwealth. ${ }^{41}$

\section{F. Employer Responsibility}

New forms of employer responsibility for the health of workers were perhaps the biggest political flashpoint in the development of Chapter 58. While rates of voluntary ESI in the Commonwealth remained high, particularly among large employers, business groups of all sizes coalesced to resist any required participation in employee health insurance. Ultimately, several provisions were enacted to encourage employers to take responsibility for the health of their workers, who would soon be required by the state to purchase health insurance. The Fair Share Contribution, ${ }^{42}$ Free Rider Surcharge, ${ }^{43}$ Section 125 cafeteria plans, ${ }^{44}$ and a Health Insurance Responsibility Disclosure form (HIRD) ${ }^{45}$

\footnotetext{
38. Id. § 1-2.

39. Id. $\S 3(16 \mathrm{~L})$.

40. Id. $\S 25(13 \mathrm{~B})$.

41. Id. $\S 3(16 \mathrm{O})$.

42. Id. $\S 188$.

43. Id. $\S 44(18 \mathrm{~B})$.

44. Id. $\S 48(2)$.

45. Id. $\S 42(6 \mathrm{C})$.
} 
would become new responsibilities for all employers with more than ten full-time equivalent employees.

The Fair Share Contribution in the Massachusetts legislation was enacted as a per worker, per year fee, not to exceed $\$ 295$, imposed on those employers who would be determined by regulation to fail to make a "fair and reasonable" contribution to the health insurance premiums of their workers. ${ }^{46}$ The amount is derived from a formula, to be recalculated annually, based on the amount of free care provided in the previous year to any uninsured workers. ${ }^{47}$ Regulations promulgated by the Division of Health Care Finance and Policy to implement the Fair Share Contribution impose a primary and secondary test: employers are exempt if $25 \%$ of their workers take up the offer of insurance (primary test), or if the employers make a $33 \%$ contribution to the workers' insurance premium (secondary test). ${ }^{48}$ The Fair Share Contribution will be collected by the Department of Labor if the employee has eleven or more full-time employees. ${ }^{49}$

Employers with more than ten employees are required to offer a Section 125 cafeteria plan for their workers to purchase health insurance with pre-tax dollars. ${ }^{50}$ No employer contribution to the plan is required. The Connector will promulgate regulations to implement this provision. ${ }^{51}$

A Free Rider Surcharge is imposed on businesses whose workers receive a certain amount of care otherwise reimbursable by the Uncompensated Care Pool or its successor, Health Safety Net Fund. ${ }^{52}$ If an employee or his dependent has three incidents of free care use in a single year, or if the employer's workers or their dependents represent an aggregate of five uses in a single year, the employer is liable to the state for a portion of the costs of that care. ${ }^{53}$ An employer will be exempt from any Free Rider Surcharge if it offers a Section 125 plan to its employees. $^{54}$

46. Id. $\S 47(188)$.

47. See Division of Health Care Finance and Policy, Executive Office of Health and human Services, The USE OF Public Health assistance IN MassachusetTs IN Fy06: EMPLOYERS WHO HAVE FIFTY OR MORE EMPLOYEES USING MASSHEALTH OR THE UNCOMPENSATED CARE POOL 5-8 available at http://www.mass.gov/Eeohhs2/docs/dhcfp/r/pubs/ 07/50+_ee_2007_report.pdf (explaining methodology).

48. 114.5 MASS. CODE REGS. 16.03 (2006), available at http://www.mass.gov/Eeohhs2/ docs/dhcfp/g/regs/114_5_16.pdf.

49. Id. $\$ 16.01$.

50. An Act Providing Access to Health Care, supra note $1, \S 48$.

51. Id.

52. Id. $\S 44$.

53. Id. $\S \S 35,44$.

54. Id. $\S 44 ; 114.5$ MASS. CODE REGS. 17.00 (postponed 2006) 
Employers and employees will be required to complete HIRD Forms pursuant to regulations by the Division of Health Care Finance and Policy. ${ }^{55}$ The forms will document offers of insurance to employees, any declination of offers, and reasons for such declination, including documentation of other coverage.

Finally, a new requirement for insurers, also affecting employers, is a new non-discrimination in offer provision. Insurers may only sell policies to employers in which all full-time employees are offered coverage at the same contribution level. No longer will employers be sold policies which discriminate among full-time employees.

As the third-rail of the employer-based health insurance system, the Employee Retirement Income Security Act of 1974 (ERISA) ${ }^{56}$ looms large in these and most other state attempts to require employers to share responsibility for the health of their workers. Presently, the Massachusetts employer responsibility provisions remain unchallenged on ERISA preemption grounds.

\section{G. Individual Mandate}

Perhaps the most controversial provision of Chapter 58 is the requirement that all individuals age eighteen years and older purchase health insurance, if it is affordable to them. ${ }^{57}$ Research shows that no more than half of the uninsured are likely to become insured in a voluntary insurance system. ${ }^{58}$ Effective July 2007, the individual mandate will help Massachusetts meet the goal of maximizing participation in insurance and expanding the insurance risk pool to lower premiums for all. The affordability contingency, however, is key. An affordability schedule will be developed and filed by the Connector annually to determine the percentage of income that one could afford to contribute per month to health insurance.

The mandate will be enforced through state tax filings. In April 2008 , when filings are made for tax year 2007, the filer will be required to state whether he or she held "creditable coverage" by December 31 , 2007. The penalty for noncompliance will be the loss of the personal exemption for that year (approximately \$219). In tax year 2008 and beyond, documentation of "creditable coverage" for each month will be

55. 114.5 MASS. CODE REGS. 18.00 (pending 2006)

56. 29 U.S.C. $\S 1001$ et seq. (2000).

57. An Act Providing Access to Health Care, supra note $1, \S 12$ (emphasis added).

58. See BLUMBERG, supra note 9 (stating that a voluntary system would reduce the uninsured by 211,000 but leave 321,000 uninsured). 
required, and the penalty will be $50 \%$ of the monthly premium of the least expensive policy affordable to the individual during the period of uninsurance. The Connector will determine what meets the definition of "creditable coverage." The Division of Insurance will maintain a database of coverage against which the filing information will be verified. The Department of Revenue will promulgate regulations, in consultation with the Connector, to enforce the mandate.

Appeals of the affordability determination by the Department of Revenue will be heard through the Connector, pursuant to Connector regulations. Religious exemptions from the mandate will be permitted and waivers will be granted on the basis of financial hardship.

\section{H. Sustainable Funding}

The Massachusetts General Court and its leadership have stated the commitment to support sustainable funding for Chapter 58, projected to be at more than $\$ 1.4$ billion at full implementation. As previously noted, the Uncompensated Care Pool combines state, federal, and private sector sources to cover over $\$ 1$ billion dollars in charges each year. ${ }^{59}$ Much of this will be shifted to cover subsidies for the newly insured. Federal matching revenue will be leveraged under the terms of the Section 1115 waiver to match some state spending and maximize available federal Medicaid funds. Revenue from the Fair Share Contribution and Free Rider Surcharge is expected to defray residual costs of care provided to uninsured workers. And, in each of the three fiscal years until full implementation, the legislature will appropriate $\$ 125$ million dollars from the General Fund.

\section{Implementation Issues}

With implementation responsibility falling on eleven executive agencies with a timeline of three years, complex implementation is anticipated and is being monitored closely by the legislature. While the first ten months of implementation saw over 100,000 newly insured residents of the Commonwealth, it also saw a transition to the new Patrick Administration. With the full support and engagement of the new administration, implementation has continued on course. Expected challenges have included the development of the first affordability scale by the Connector-the difficult task delegated to it by the legislature-

59. See supra note 5 and accompanying text. 
and procurement by the Connector of new, affordable insurance products by the state's insurers. As well, the determination by the Connector of what constitutes "creditable coverage" will set the standard for adequate health insurance coverage; per the statement of legislative leaders, the problem of uninsurance in Massachusetts will not be replaced with one of underinsurance. Vigilance by all stakeholders will be needed, as the legislature is prepared to make adjustments to the statutory language as implementation proceeds and as areas meriting further legislative review are identified and addressed.

\section{CONCLUSION}

The decade of the 1990's was marked by rising numbers of uninsured, rising health care costs and health insurance premiums, and increased pressure from the federal government on states to reign in Medicaid program costs. The spring of 2006 marked the beginning of a new phase for state health reform when the Massachusetts Legislature enacted "An Act Providing Access to Affordable, Quality, Accountable Health Care." The momentum begun by significant state-level action to effect large-scale expansion of access to health insurance for its residents has spread to other states and to the platforms of the field of presidential candidates. As debates continue among states and in Congress, legal issues imbedded in the range of state reforms will evolve along with the progress of efforts to reform the private insurance market and to create new access to existing public programs. 
$* * *$ 